\title{
Comparative effect of sodium chloride and sodium sulfate on the biomass and quantitative changes in starch, protein and total soluble sugar in pea seeds (Pisum sativum L.)
}

\author{
Gulafshan $^{1}$, Farha Rehman ${ }^{1}$, Sumaira J. Khan ${ }^{1}$, Iram Khan Tahir ${ }^{2}$ and Azra Shaheen ${ }^{2}$ \\ ${ }^{1}$ Department of Botany, Mohammad Ali Jauhar University, Rampur, Uttar Pradesh, India \\ ${ }^{2}$ Department of Zoology, Mohammad Ali Jauhar University, Rampur, Uttar Pradesh, India
}

*Corresponding Author: gulbotany123@gmail.com

[Accepted: 07 December 2020]

\begin{abstract}
The nature of the soil is a very important factor in the growth and development of a crop. Crop plants suffer a decline in growth and yield, when exposed to the saline condition. Pea considers one of the main leguminous crops, due to its ability to produce significant quantities of protein, carbohydrates and nutrient-rich seeds. Plants were subjected to four salt treatments, 4, 8, 12 and 16 mmhos $\mathrm{cm}^{-1}$ of sodium chloride and sodium sulfate and the biomass and biochemical responses were measured. All growth attributes such as stem, root and leaf fresh and dry weight decrease with the increased salinities doses. Salt treatments were no significant effects on the biomass and quantitative changes in starch, protein and soluble sugar in seeds of pea. But it was noted that the starch contents were much reduced in $16 \mathrm{mmhos} \mathrm{cm}^{-1}$, the salinity level of sodium chloride and sodium sulfate as compared to control. The protein content and sugar content value were increased in a higher concentration of sodium chloride and sodium sulfate, when compared to control in Pea, CV. Azad P-1. The proline content increased with salt stress up to $8 \mathrm{mmhos} \mathrm{cm}^{-1}$ in CV-Azad P-1. It was also observed that the high dose of sodium sulfate is declined biomass and quantitative changes in starch, than that of sodium chloride solution in pea seeds.
\end{abstract}

Keywords: Quantitative - Biomass - Soluble sugar - $\mathrm{Na}_{2} \mathrm{So}_{4}$, - Azad P-1.

[Cite as: Gulafshan, Rehman F, Khan SJ, Tahir IK \& Shaheen A (2020) Comparative effect of sodium chloride and sodium sulfate on the biomass and quantitative changes in starch, protein and total soluble sugar in pea seeds (Pisum sativum L.). Tropical Plant Research 7(3): 638-644]

\section{INTRODUCTION}

Garden pea (Pisum sativum L.) is a very popular nutritious vegetable crop, belong to family Fabaceae and grown in many of the middle-eastern countries. Pea is an important legume vegetable, consumed both as grain legumes and as a vegetable. Its seeds contain $18-20 \%$ dry matter whose $10-12 \%$ carbohydrate and $5-8 \%$ is protein (Vural et al. 2000). The plant grown under salinity conditions are stressed in three ways; phytotoxicity of $\mathrm{Na}^{+}$and $\mathrm{Cl}^{-}$ions, decreased water potential in the rhizosphere which caused water deficit and nutrient imbalance by the reduction in the uptake and/or shoot transport (Marschner et al. 1995). Sowires et al. (1997) reported biochemical changes associated with salt stress in Pea and Bean tissue culture. They found the concentration of sodium, carbohydrates and free proline generally increased with an increasing salinity level of sodium chloride. Negrao et al. (2017) observed that the soil salinity is a major abiotic constraint affecting crop yields such as relative growth rate, water relation, transpiration, transpiration use efficiency, ionic relations, photosynthesis, senescence, yield and yield components. Alam et al. (2015) reported that the salinity effect was evaluated based on of biomass yield reduction, physiological attributes. Ghosh et al. (2016) studied that the salinity has been a key abiotic constraint devastating crop production worldwide. According to Zribi et al. (2009) and Giuffrida et al. (2013), salinity reduced root bio mass in Broccoli and Cauliflower. Sodium, chlorine and boron are some elements, which have specific toxic effects on plants. Excessive accumulation of sodium in cell walls can rapidly lead to osmotic stress and cell death (Munns 2002). Salinity reduces yields and effects physiology and biochemistry of plants. Seed germination, water deficit, ion balance of the cellular ions and 
osmotic stress is affected by salinity (Khan et al. 2002, Khan \& Panda 2008). Ion toxicity and osmotic stress cause metabolic imbalance, which in turn leads to oxidative stress (Chinnusamy et al. 2006). Sodium sulphate $\left(\mathrm{Na}_{2} \mathrm{So}_{4}\right)$ is the dominant salt in alkaline soils, therefore sodium exists in the soil solution as well as on clay surfaces. Consequently, salinity stresses the plants in two ways, i. higher concentrations of salts in the soil make it harder for roots to extract water (osmotic stress), and ii. high salt level within the plant may be harmful (specific ion toxicity) (Munns \& Tester 2008, Hussain et al. 2008). The salt ions like present in the $\mathrm{Na}^{+}, \mathrm{SO}_{4}{ }^{-2}$ soil complete with the uptake of other nutrient ions like $\mathrm{K}^{+}, \mathrm{Ca}^{2+}$, etc. which results in the nutritional disorder and eventually leads to reduce the quality and yield of plants (Grattan \& Grieve 1999). Salinity can also be affected protein content negatively or positively when treated with different doses of salt concentration (Tort \& Turkyilmaz 2004, Beltagi et al. 2006, Chen et al. 2007, Kapoor \& Srivastava (2010). Thus, in the present study, an attempt has been made to understand the comparative effects of sodium chloride and sodium sulfate on the biomass and quantitative changes in soluble sugar, protein and starch of pea seeds (Pisum sativum) in cultivar Azad P-1.

\section{MATERIAL AND METHOD}

\section{Plant material and culture}

Investigate the comparative effect of salt stress on biomass and chemical parameter of Pea CV Azad P-1 will be screened out in Pod condition. Pea plants were grown in green houses and irrigated three time a week. After one month the plants were treated with different salinity level $\left(4,8,12\right.$ and 16 mmhos cm $\left.{ }^{-1}\right)$ of $\mathrm{NaCl}$ and $\mathrm{Na}_{2} \mathrm{So}_{4}$, according to Richard (1954). Treatments were completed during three consecutive weeks and the pots irrigated with distilled water every three days. After 95 days, the plants were selected and taken out of the soil carefully without damaging the root system, measured and analyzed. A total of three replicates were chosen for analysis of growth and biochemical measurement. All the data were statistically analysed using Completely Randomized Design (CRD) with three replications.

\section{Growth measurement}

The relative stress induced inhabitation of biomass was estimated by determining the number of growth parameters in the control and the stressed plants, after 95 days after sowing. Plants were harvested for growth measurement. The fresh weight of root, stem and leaves were measured immediately. The dry weight were measured by drying the root, stem and leaves of the plants at $80^{\circ} \mathrm{C}$ to give a constant weight. Weight of the dry samples were recorded with the help of an electronic balance.

\section{Determination of proline}

Proline was determined by using ninhydrin reagent and measured according to Bates et al. (1973). Proline was extracted from $0.5 \mathrm{~g}$ of fresh leaf in $10 \mathrm{ml}$ of $3 \%$ sulfosalicylic acid. $2 \mathrm{ml}$. of the extract was reacted with two ml. of glacial acetic acid for $75 \mathrm{~min}$ at $100^{\circ} \mathrm{C}$ and incubated in an ice bath and the reaction mixture was extracted with adding $4 \mathrm{ml}$. of toluene. The extract was vortexed for 20 second. The absorbance of toluene layer was spectrophotometrically determined at a wave length of $520 \mathrm{~nm}$. Concentration was determined from a standard curve and calculatedon a fresh weight basis (meo mol prolineg- ${ }^{1} \mathrm{fw}^{-1}$ ).

\section{Soluble sugar estimation}

95 days old plants were carefully drag out from the pots. Pod of pea were collected and then taken out of the seeds in the pods. For soluble sugar contents, the sample was oven dried for $24 \mathrm{hrs}$. at $80^{\circ} \mathrm{C}$. Soluble sugar was estimated in the ethanol soluble fraction as described by Nelson (1944). $100 \mathrm{mg}$ of oven-dried sample (pea seed) was extracted in $80 \%$ ethanol. $0.5 \mathrm{ml}$ aliquot was taken in a test tube and volume was made to $1 \mathrm{ml}$ with double distilled water. After adding $1 \mathrm{ml}$ copper reagent, the tube were bath for 20 minutes and then cooled at room temperature. Added $1 \mathrm{ml}$ arsenomolybedate reagent than to each test tube. The final volume was made to $10 \mathrm{ml}$ with distilled water. The absorbance was measured at $570 \mathrm{~nm}$ and expressed as $\mathrm{mg} \mathrm{g}{ }^{1}{ }^{1}$ dry weight.

\section{Protein estimation}

Protein (mg g- ${ }^{1}$ fresh weight of seed) was measured by the method of Lowry et al. (1951). (I) $5 \mathrm{ml}$ of the copper solution was added to tubes containing $0.1 \mathrm{ml}$ of the protein extract. The copper solution composed of (a) $100 \mathrm{ml}$ of sodium chloride $(0.1 \mathrm{~N})$ in which were dissolved, $2 \mathrm{~g}$ of anhydrous sodium carbonates and $1 \mathrm{ml}$. of sodium tartrate (2.7\%) (b) $1 \mathrm{ml}$ of copper sulphate (1\%). (a \&b) were mixed immediately before use and the tubes were left for 15 minutes, then the optical density (o.D.) was measured at $570 \mathrm{~nm}$. (II) The same steps were repeated with the standard solution (of Known conc.) of Bovine Serum Albumin. (III) Step (I and II) were 
repeated thrice and the mean value of the three readings were compared with the standard curve of Bovine Serum Albumin.

\section{Starch estimation}

Starch content was estimated using the method of Paleg (1960). Fresh plant material (pea seed) was weight and transferred to pyrex stopper tubes containing $15 \mathrm{ml}$. of $80 \%$ ethanol and placed in a boiling water bath .The sample was homogenized and centrifuged. The residue was dissolved in $20 \mathrm{ml} .0 .7 \% \mathrm{KOH}$ and it was gelatinized in boiling water bath for 40 minutes, cooled and centrifuged. Standard solution of $2 \%$ starch was prepared in $0.7 \% \mathrm{KOH}$. The final volume was made to $10 \mathrm{ml}$ with distilled water and the absorbance was measured at $600 \mathrm{~nm}$.

\section{RESULTS AND DISCUSSION}

\section{Biomass}
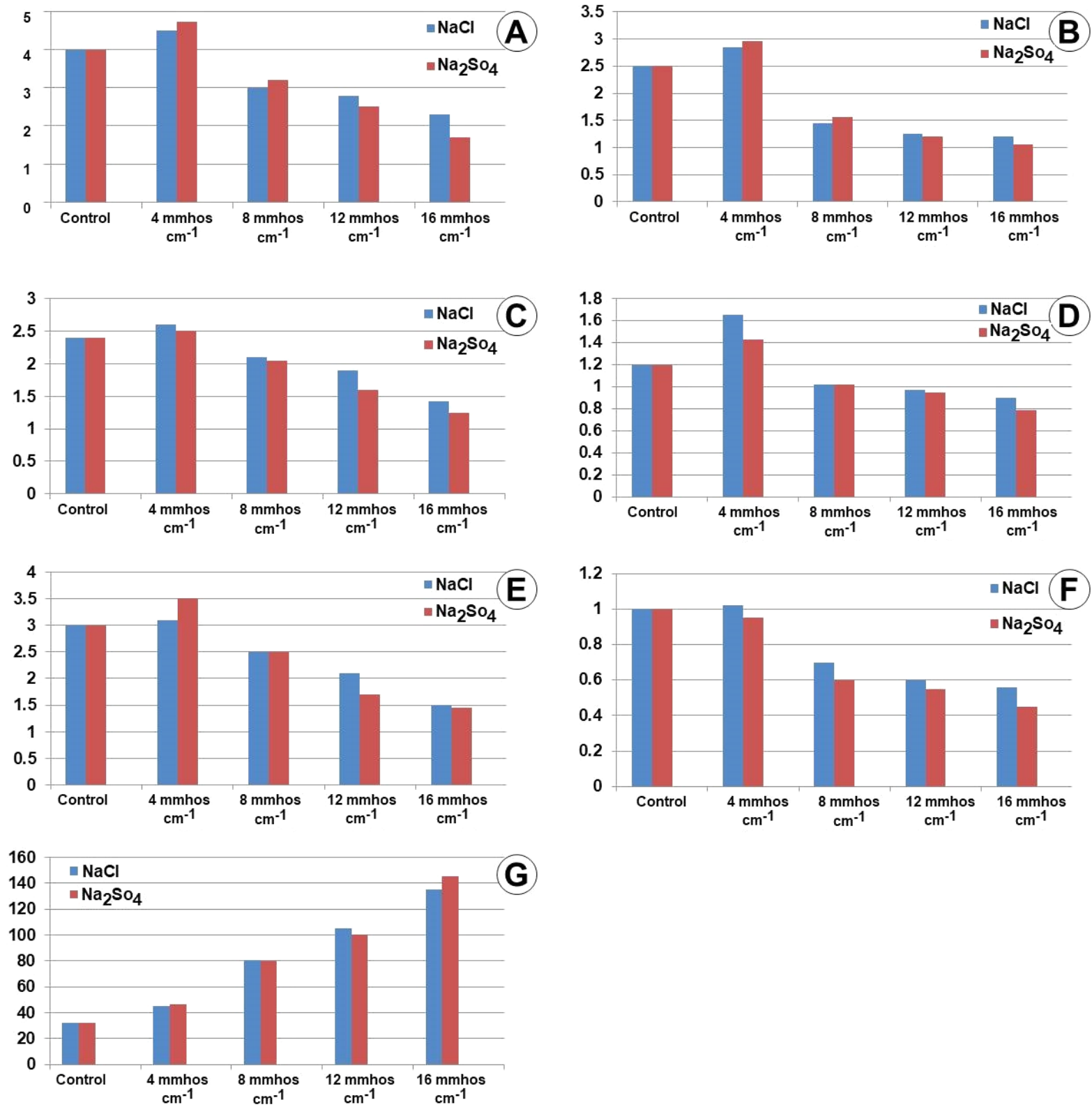

Figure 1. Effect of treatment with different concentration of $\mathrm{NaCl}$ and $\mathrm{Na}_{2} \mathrm{So}_{4}$ : A, Stem f.w. (g); B, Stem d.w. (g); C, Root f.w. (g); D, Root d.w. (g); E, Leaf f.w. (g); F, Leaf d.w. (g); G, Proline ( $\mu \mathrm{g} \mathrm{g}{ }^{-}{ }^{1}$ f.w. of leaf) of pea.

Going through the data in table 1 and figure 1, it is obvious that there is a negative effect for salt stress on the fresh and dry weight Stem, Root and Leaf of the Pea CV. Azad P1. The data indicates that control had a more fresh and dry weight of stem in comparison to salinity level of 8, 12 and 16 mmhoscm- $^{1}$ of sodium chloride and sodium sulfate. The maximum increase in fresh and dry weight of stem were achieved by using the minimum concentration $\left(4 \mathrm{mmhos} \mathrm{cm}^{-1}\right)$. These result for fresh and dry weights in this study, agree with the result presented by Dantus et al. (2005), in their study on cowpea (Vigna unguiculata L.), where they report that www.tropicalplantresearch.com 
using $10 \mathrm{mM}$ of sodium chloride increased fresh and dry weights of shoot system of their seedlings. The salinity

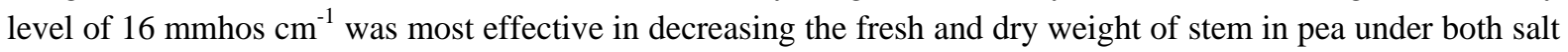
treatments. The result showed that excess of salt significantly reduced root fresh and dry weight due to reduced osmotic potential. In general excess salt, root zone has harmful effects on growth in plants. Fresh weight and dry weight of root gradually decreased with an increase in both salt treatments. Gomes et al. (2015) reported that excess salinity reduces growth and development and may even cause plant death because of the greater osmotic effect outside the root and the resulting restriction in water flow from the soil into plants, which plant need if they are to survive and grow under salt stress conditions. The reduction were more pronounced at higher concentration of $\mathrm{Na}_{2} \mathrm{So}_{4}$, due to the increased toxicity of sulfate over chloride rather than a promotion of sodium toxicity by sulfate. It was noted that salt stress also decreased the total fresh and dry weight of leaves in comparison to control. The fresh and dry weight of leaves significantly more decreased under the different concentration of $\mathrm{Na}_{2} \mathrm{So}_{4}$ in comparison to different concentration of $\mathrm{NaCl}$ in Pea. The salinity level of 16 mmhos $\mathrm{cm}^{-1}$ of $\mathrm{NaCl}$ and $\mathrm{Na}_{2} \mathrm{So}_{4}$ significantly reduced fresh and dry weight of leaf in $\mathrm{CV}$. AzadP1, to respective control.

Table 1. Effect of treatment with different concentration of $\mathrm{NaCl}$ and $\mathrm{Na}_{2} \mathrm{So}_{4}$ on Biomass (g per plant) of pea.

\begin{tabular}{|c|c|c|c|c|c|c|c|c|}
\hline \multirow{2}{*}{$\begin{array}{l}\text { Treatment } \\
\left(\mathbf{m m h o s} \mathbf{c m}^{-1}\right)\end{array}$} & \multicolumn{2}{|c|}{ Stem f.w. (g) } & \multicolumn{2}{|c|}{ Stem d.w. (g) } & \multicolumn{2}{|c|}{ Root f.w. (g) } & \multicolumn{2}{|c|}{ Root d.w. (g) } \\
\hline & $\mathrm{NaCl}$ & $\mathrm{Na}_{2} \mathrm{So}_{4}$ & $\mathrm{NaCl}$ & $\mathrm{Na}_{2} \mathrm{So}_{4}$ & $\mathrm{NaCl}$ & $\mathrm{Na}_{2} \mathrm{So}_{4}$ & $\mathrm{NaCl}$ & $\mathrm{Na}_{2} \mathbf{S o}_{4}$ \\
\hline Control & 4.0 & 4.0 & 2.4 & 2.4 & 2.5 & 2.5 & 1.2 & 1.2 \\
\hline 4 & 4.5 & 4.75 & 2.60 & 2.5 & 2.85 & 2.96 & 1.65 & 1.43 \\
\hline 8 & 3.0 & 3.2 & 2.1 & 2.05 & 1.45 & 1.56 & 1.02 & 1.02 \\
\hline 12 & 2.8 & 2.5 & 1.9 & 1.6 & 1.25 & 1.2 & 0.97 & 0.95 \\
\hline 16 & 2.3 & 1.7 & 1.42 & 1.25 & 1.2 & 1.05 & 0.9 & 0.79 \\
\hline CD at $5 \%$ & & $=1.47$ & & $=0.90$ & & $=0.86$ & & $=0.78$ \\
\hline $\mathbf{S E}=$ & & $=0.64$ & & $=0.39$ & & $=0.37$ & & $=0.33$ \\
\hline
\end{tabular}

Proline

The data given in table 2 represents the proline content as affected by chemical treatments. Proline content ( $\mu \mathrm{g} \mathrm{g}^{-1}$ fresh weight of leaf) increased with both salt concentrations ranging from 4, 8, 12, \& $16 \mathrm{mmhos} \mathrm{cm}^{-1}$, but the moderate and high salinities induced a significant increase in proline content in the fresh leaves of cultivar Azad P1. In salt tolerant and salt sensitive cultivars of many crops, proline accumulation is a primary defense which response to maintain the osmotic pressure in a cell (Misra \& Gupta 2005). There was a linear increase in free proline accumulation with increasing severity and duration of stress. Our results are in agreement with those previously reported for Pisum variety (Hokmabadi et al. 2005, Karimi et al. 2014).

Table 2. Effect of treatment with different concentration of $\mathrm{NaCl}$ and $\mathrm{Na}_{2} \mathrm{So}_{4}$ on Leaf fresh and dry weight (g per plant) and Proline ( $\mu \mathrm{g} \mathrm{g}^{1}{ }^{1}$ f.w. of leaf) of pea.

\begin{tabular}{|c|c|c|c|c|c|c|}
\hline \multirow{2}{*}{$\begin{array}{l}\text { Treatment } \\
\left(\mathbf{m m h o s} \mathbf{c m}^{-1}\right)\end{array}$} & \multicolumn{2}{|c|}{ Leaf f.w. (g) } & \multicolumn{2}{|c|}{ Leaf d.w. (g) } & \multicolumn{2}{|c|}{ Proline ( $\mu \mathrm{g} \mathrm{g}^{-1}$ f.w. of leaf) } \\
\hline & $\mathrm{NaCl}$ & $\mathrm{Na}_{2} \mathrm{So}_{4}$ & $\mathrm{NaCl}$ & $\mathrm{Na}_{2} \mathrm{So}_{4}$ & $\mathrm{NaCl}$ & $\mathrm{Na}_{2} \mathrm{So}_{4}$ \\
\hline Control & 3.0 & 3.0 & 1.0 & 1.0 & 32.25 & 32.25 \\
\hline 4 & 3.1 & 3.5 & 1.02 & 0.95 & 45.35 & 46.12 \\
\hline 8 & 2.5 & 2.5 & 0.7 & 0.6 & 80.51 & 79.85 \\
\hline 12 & 2.1 & 1.7 & 0.6 & 0.55 & 105.25 & 100.20 \\
\hline 16 & 1.5 & 1.45 & 0.56 & 0.45 & 135.07 & 145.54 \\
\hline CD at5\% & & $=1.29$ & & $=0.26$ & & $=25.18$ \\
\hline $\mathbf{S E}=$ & & $=0.56$ & & $=0.11$ & & $=9.05$ \\
\hline
\end{tabular}

Soluble sugar

Salinity stress influenced soluble sugar in pea seed of CV. Azad P1, shown in table 3 and figure 2. A significant increase in the soluble sugar contents was observed in dry seeds of Pea at moderate and high salinities of $\mathrm{NaCl}$ and $\mathrm{Na}_{2} \mathrm{So}_{4}$. Soluble sugar contents were increased gradually by increasing both salt concentrations. The data indicates that a higher concentration of sodium sulfate had more increase $\left(13.25 \mathrm{mg} \mathrm{g}^{-}\right.$ $\left.{ }^{1}\right)$ soluble sugars in comparison to a high concentration of sodium chloride $\left(12.57 \mathrm{mg} \mathrm{g}^{-1}\right)$. According to (ChelliChaabouni et al. 2010), stress plants accumulate compatible solutes such as soluble sugars and proline, which are known for their osmoprotection activity.

\section{Protein}

In table 3, results indicate a positive effect for $\mathrm{NaCl}$ and $\mathrm{Na}_{2} \mathrm{So}_{4}$ using various concentration on the total protein of pea seeds. It appears from the data that there was a general increase in protein content that corresponded with the increase in both salt concentrations. Salinity level of $16 \mathrm{mmhos} \mathrm{cm}^{-1}$ was most effective 
in increasing the protein content in pea seeds under both salt treatments. Kapoor \& Srivastava (2010) observed an increase in protein content when increasing salt concentration on Vigna mungo L.

Table 3. Effect of treatment with different concentration of $\mathrm{NaCl}$ and $\mathrm{Na}_{2} \mathrm{So}_{4}$ on Soluble sugar (mg g ${ }^{-1}$ d.w.), Protein ( $\mathrm{mg} \mathrm{g}^{-1}$ f.w.) and Starch ( $\mathrm{mg} \mathrm{g}^{-1}$ f.w.) of pea.

\begin{tabular}{|c|c|c|c|c|c|c|}
\hline \multirow{2}{*}{$\begin{array}{l}\text { Treatment } \\
\left(\mathrm{mmhos} \mathrm{cm}{ }^{-1}\right)\end{array}$} & \multicolumn{2}{|c|}{ Soluble sugar $\left(\mathrm{mg} \mathrm{g}^{-1} \mathrm{~d} . w\right)$} & \multicolumn{2}{|c|}{ Protein (mg g ${ }^{-1}$ f.w.) } & \multicolumn{2}{|c|}{ Starch (mg g ${ }^{-1}$ f.w.) } \\
\hline & $\mathrm{NaCl}$ & $\mathrm{Na}_{2} \mathrm{So}_{4}$ & $\mathrm{NaCl}$ & $\mathrm{Na}_{2} \mathrm{So}_{4}$ & $\mathrm{NaCl}$ & $\mathrm{Na}_{2} \mathrm{So}_{4}$ \\
\hline Control & 8.22 & 8.22 & 28.04 & 28.04 & 42.23 & 42.23 \\
\hline 4 & 9.15 & 8.97 & 30.15 & 31.29 & 39.27 & 35.26 \\
\hline 8 & 11.05 & 10.05 & 35.50 & 36.15 & 32.18 & 30.05 \\
\hline 12 & 11.51 & 12.67 & 40.45 & 40.95 & 27.37 & 24.15 \\
\hline 16 & 12.57 & 13.25 & 45.25 & 47.28 & 20.14 & 18.15 \\
\hline CD at5\% & & $=1.05$ & & $=4.06$ & & $=5.24$ \\
\hline $\mathrm{SE}=$ & & $=0.34$ & & $=1.67$ & & $=2.09$ \\
\hline
\end{tabular}
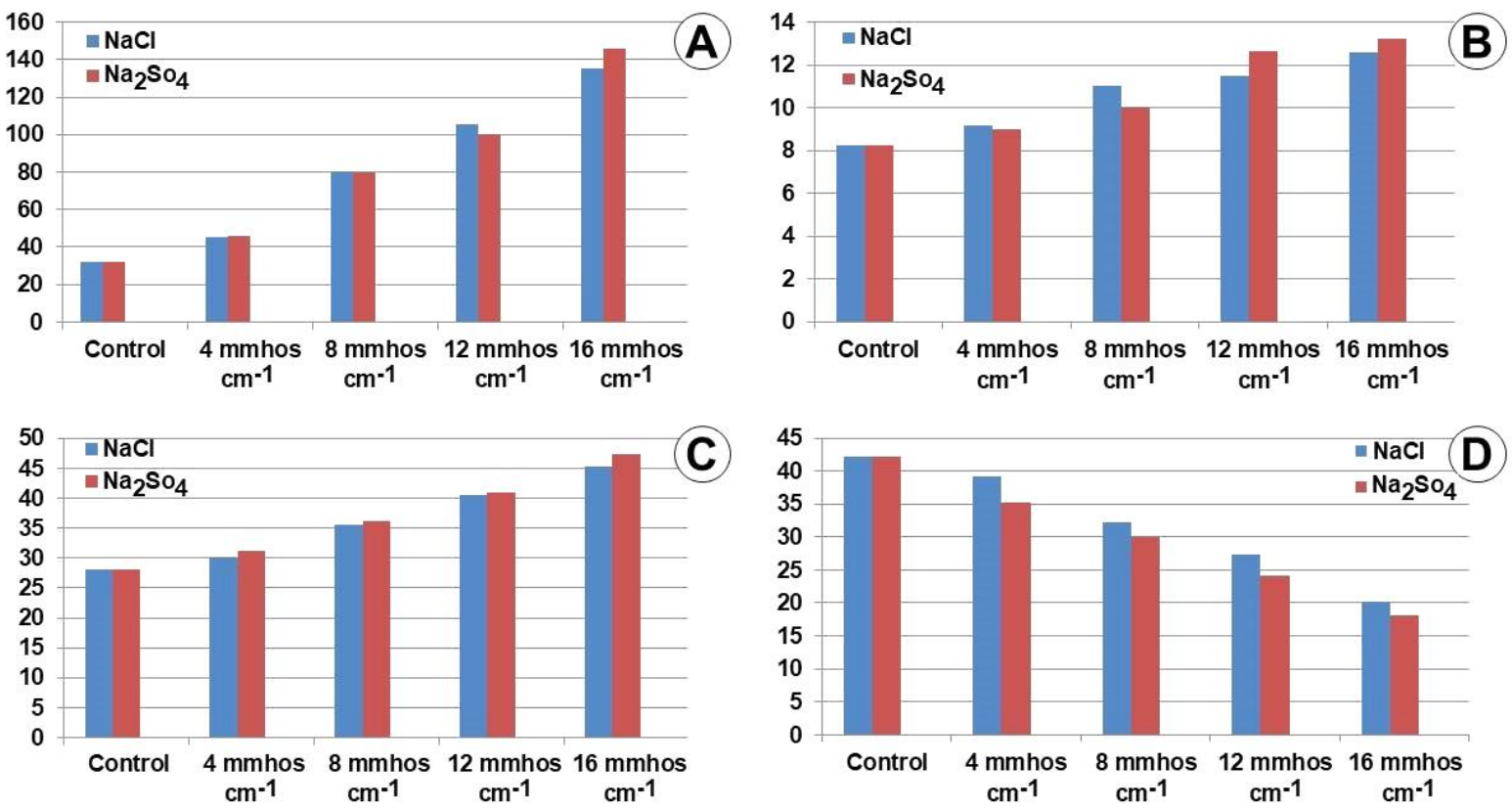

Figure 2. Effect of treatment with different concentration of $\mathrm{NaCl}$ and $\mathrm{Na}_{2} \mathrm{So}_{4}$ : A, Proline ( $\mu \mathrm{g}$ g- ${ }^{1}$ f.w. of leaf); B, Soluble sugar mg g- ${ }^{1}$ d.w.; C, Protein (mg g- ${ }^{1}$ f.w.); D, Starch (mg g- ${ }^{1}$ f.w.) of pea.

Starch

Table 3 and figure 2 indicate the data on starch contents ( $\mathrm{mg} \mathrm{g}^{-1} \mathrm{fw}$.) as affected by $\mathrm{NaCl}$ and $\mathrm{Na}_{2} \mathrm{So}_{4} \mathrm{salts}_{\text {. }}$ The starch content value was $42.23 \mathrm{mg} \mathrm{g}^{-1} \mathrm{fw}$ in control. On the other side, values were $20.14 \mathrm{mg} \mathrm{g}^{-1}$ and 18.15 $\mathrm{mg} \mathrm{g}^{-1}$ in salinity level of $16 \mathrm{mmhos} \mathrm{cm}^{-1}$ of sodium chloride and Sodium sulfate treatments. It was noted that the starch content was much reduced in a higher concentration of $\mathrm{NaCl}$ and $\mathrm{Na}_{2} \mathrm{So}_{4}$.

\section{CONCLUSION}

In the present study the adverse effect of salt stress decreased the biomass of pea plants. The reduction of biomass could be attributed to the osmotic effect of salinity stress which caused an increase of growth inhibitors, decreased growth promoter and disturbance of water in plant grown under salt stress. The reduction were more in a higher concentration of $\mathrm{Na}_{2} \mathrm{So}_{4}$, due to the increased toxicity of sulfate over chloride rather than a promotion of sodium toxicity by sulfate. Starch contents were much reduced in high salinity level of sodium chloride and sodium sulfate, but the protein content and sugar content value were increased in a higher concentration of both salt stress. Salt stress registered a significant increase in proline content which support the hypothesis that proline acts as a protective compound during salt stress. These organic solutes could be used as a biochemical indicator for increased salt tolerance in the pea.

\section{ACKNOWLEDGEMENTS}

The authors are thankful to the head, department of botany, Mohammad Ali Jauhar University, for providing necessary facilities. 


\section{REFERENCE}

Alam MA, Abdul MYR \& Azizah AH (2015) Effect of salinity on Biomass, Yield and Physiological and StemRoot Anatomical Characteristic of Purslane (Portulaca oleracea L.) Accessions, Bio Med Research International 15: 105-695.

Bates LS, Waldren RP \& Teare ID (1973) Rapid determination of free proline for water stress studies. Plant and Soil 39: 205-207.

Beltagi MS, Ismail MA \& Mohamed FH (2006) Induced salt tolerance in common bean (Phaseolus vulgaris L.) by gamma irradiation. Pakistan. Journal Biological Science 6: 1143-1148.

Chelli-Chaabouni A, Ben Mosbah A, Maalej M, Gargouri K, Gargouri- Bouzid R \&Drira N (2010) In vitro salinity tolerance of two pistachio rootstock : Pistacia vera L. and P. atlantica Desf. Environmetal and Experimental Botany 69: 302-312.

Chen C, Tao C, Peng H \& Ding Y (2007) Genetic analysis of salt stress responses in asparagus bean (Vigna unguiculata L. ssp. sesquipedalis verdc. ). Jouurnal Hered 98(7): 655-665.

Chinnusamy V, Zhu J \& Zhu J-K (2006) Gene regulation during cold acclimation in plants. Physiologia Plantarum 126(1): 52-61.

Dantus BF, Ribeiro L \& Aragao CA (2005) Physiological response of cowpea seeds to salinity stress. Revista Brasileira de Sementes 27(1): 144-148.

Ghosh B, Ali MN \& Saikat G (2016) Response of Rice under salinity stress. Journal of Rice Research 4: 167.

Giuffrida F, Scuderi D, Giurato R \& Leonardi C (2013) Physiological response of broccoli and cauliflower as affected by $\mathrm{NaCl}$ salinity. ISHS Acta Horticulturae 1005: 435-441.

Gomes GR, Almeida IHC \& Takahashi ISA ( 2015) Efeito do estresse hidrico e salino no vigor germinaco de sementes de feijao - vagem. (phaseolus vulgaris L.). Cultura Agronomica 24: 83-92.

Grattan SR \& Grieve CM (1999) Salinity-mineral nutrient relations in horticultural crops. Scientia Horticulturae 78: $127-157$.

Hokmabadi H, Arzani K \& Grierson PF (2005) Growth, chemical composition and carbon isotope Discrimination of Pistachio (Pistaacia vera L.) root stock seedling in response to salinity. Australlia Journal Agricalture Research 56: 135-144.

Hussain T, Chandrasekhar T, Hazara M \& Sultan Z (2008) Recent advances in salt stress biology - a review. Molecular Biology Reports 3(1): 8-13.

Kapoor K \& Srivastava A (2010) Assessment of salinity tolerance of Vinga mungo var. Pu-19 using ex vitro and in vitro methods. Asian Journal of Biotechnology 2(2): 73-85.

Karimi HK \& Maleki Kuhbanani A (2015) The evaluation of inter-specific hybrid of P. atlantica* P.vera cv.'Badami-Rice-Zarand 'as a pistachio rootstock to salinity stress. Journal of Nuts 6(2): 113-122.

Khan MH \& Panda SK (2008) Alternation in root lipid peroxidationand antioxidative Responses in two rice cultivars under $\mathrm{NaCl}$ salinity stress. Acta Physiologiae Plantarum 30: 89-91.

Khan MH, Singha LB \& Panda SK (2002) Changes in antioxidant levels in Oriza sativa L. Roots subjected to NaCl-salinity stress. Acta Physiology Plant 24: 145-148.

Lowry OH, Rosebrough NJ, Farr AL \& Randall RJ (1951) Protein measurement with the Folin phenol reagent Journal Biology Chemistry 193(1): 265-275.

Marschner H (1995) Mineral Nutrition of Higher plants, $2^{\text {nd }}$ Edn, Academic press, London, UK, pp. 596-680.

Misra N \& Gupta AK (2005) Effect of salt stress on proline metabolism in two high yield genotype of green gram. Plant Science 169: 331-339.

Munns R \& Tester M (2008) Mechanism of salinity tolerance. Annual Rev. Plant Biology 59: 651-681.

Munns R (2002) Comparative physiology of salt and water stress. Plant, Cell \& Environment 25(2): 239-250.

Negrao S, Schmockel SM \& Tester M (2017) Evaluating physiological Responses of plants to salinity stress. Annals of Botany 119: 1.

Nelson N (1994) A photometric adaptation of somoygi method for the determination of glucose. Journal Biology Chemistry 153: 375-380.

Paleg LG (1960) Physiological effect of gibberellic acid 11 starch hydrolyzing enzyme of barley endosperm. Plant Physiology 35: 902-906.

Richard LA (1954) Diagnosis and improvement of saline and alkaline soils. U.S. Department of Agricultural,Washington, USA, $160 \mathrm{p}$.

Sowires ES, Saker MM \& EL-Bahr MK (1997) Biochemical changes associated with salt stress in Pea and Bean tissue cultures. Egyptain Journal of Horticulture 24(2): 161-173. 
Tort N \& Turkyilmaz B (2004) A physiological investigation on the mechanisms of salinity tolerance in some barley culture forms. Journal of Food Security 27: 1-16.

Vural H, Esiyok D \& Duman I (2000) Kültür sebzeleri (sebze yetiştirme). Ege Üniversitesi Ziraat Fakül- tesi Bahçe Bitkileri Bölümü, Bornova-İzmir, Turkey, 440 p.

Zribi L, Gharbi F, Rezgui F, Rejeb S, Nahdi H \& Rejeb MN (2009) Application of chlorophyll fluorescence for the diagnosis of salt stress in tomato Solanum lycopersicum (variety RioGrande). Science Horticulture 120: $367-372$. 